Creative Commons User License: CC BY-NC-ND

Abstracted by: EBSCOhost, Electronic Journals Service (EJS), Google Scholar, Journal Seek, Scientific Commons,

Food and Agricultural Organization (FAO), CABI and Scopus

http://eoi.citefactor.org/10.11226/v23i2
Journal of Agricultural Extension

Vol. 23 (2) April, 2019

ISSN(e): 24086851; ISSN(Print); 1119944X

http://journal.aesonnigeria.org

http://www.ajol.info/index.php/jae

Email: editorinchief@aesonnigeria.org

\title{
Factors Influencing Use of Information and Communication Technologies among Farmers in Rural Punjab, Pakistan \\ https://dx.doi.org/10.4314/iae.v23i2.11
}

\section{Muhammad Luqman}

College of Agriculture, University of Sargodha, Sargodha-Pakistan

email: muhammad.luqman@uos.edu.pk, phone: +923143087150

\section{Muhammad Yaseen}

College of Agriculture, University of Sargodha, Sargodha-Pakistan

email: yaseen.baksh@uos.edu.pk, phone: +923336533416

\section{Saleem Ashraf}

In-service Agriculture Training Institute, Rahim Yar Khan, Pakistan email: saleem1828@gmail.com, phone: +923437601947

\section{Muhammad Umer Mehmood}

College of Agriculture, University of Sargodha, Sargodha-Pakistan email: umersaqi145@gmail.com, phone: +923340657271

\section{Mujahid Karim}

College of Agriculture, University of Sargodha, Sargodha-Pakistan

email: mujahid6868@gmail.com, phone: +923036868702

\section{Abstract}

This study explored the factors influencing the application of Information and Communication Technologies (ICTs) among farmers in the Punjab province of Pakistan. The Punjab province is divided into three agro-ecological zones viz Northern, Central and Southern. In this study, one district from each zone was randomly selected. Total sample size comprises of 150 farmers. Farmers were interviewed using a self-administered interview schedule comprising of open and close-ended questions. Respondents' access to ICTs was low level. Chi-square test revealed a significant association between the age of respondents and adoption of ICTs. Young respondents were leading users of ICTs in the study area. Size of landholding and income level of the respondents had a significant association with the frequency of use of ICTs in agriculture. Among various ICTs tools, mobile/cell phone attracted $47.3 \%$ of respondents to access agricultural information. Factors militating use of ICTs include; electricity/power issues $(\bar{x}=2.95 / 3.00)$, language barriers $(\bar{x}=2.93 / 3.00)$, limited knowledge and skills about ICTs ( $\bar{x}=2.89 / 3.00)$, high cost $(\bar{x}=2.87 / 3.00)$ and limited availability of ICTs $(\bar{x}=2.85 / 3.00)$. Extent of ICTs use to access agricultural information can surge with the unit income level rise, enhanced access to ICTs and enhanced skill level to use ICTs.

Keywords: Agriculture information, small landholders, ICTs, rural Punjab

\section{Introduction}

One of the most important challenges which are being faced in many of the developing regions of the world is poverty reduction and to ensure sustainable food production to feed ever increasing population. This has been estimated that the global population would be around 9 Billion by 2050 . In this situation, development experts and academicians from all over the globe are much worried on how to provide food on a sustained basis (Ehrlich \& Harte, 2015). The data presented in Figure 1 shows that there is a continuous increase in population in developing countries. 
Creative Commons User License: CC BY-NC-ND

Abstracted by: EBSCOhost, Electronic Journals Service (EJS), Google Scholar, Journal Seek, Scientific Commons,

Food and Agricultural Organization (FAO), CABI and Scopus
Journal of Agricultural Extension

Vol. 23 (2) April, 2019

ISSN(e): 24086851; ISSN(Print); 1119944X

http://journal.aesonnigeria.org

http://www.ajol.info/index.php/jae

Email: editorinchief@aesonnigeria.org

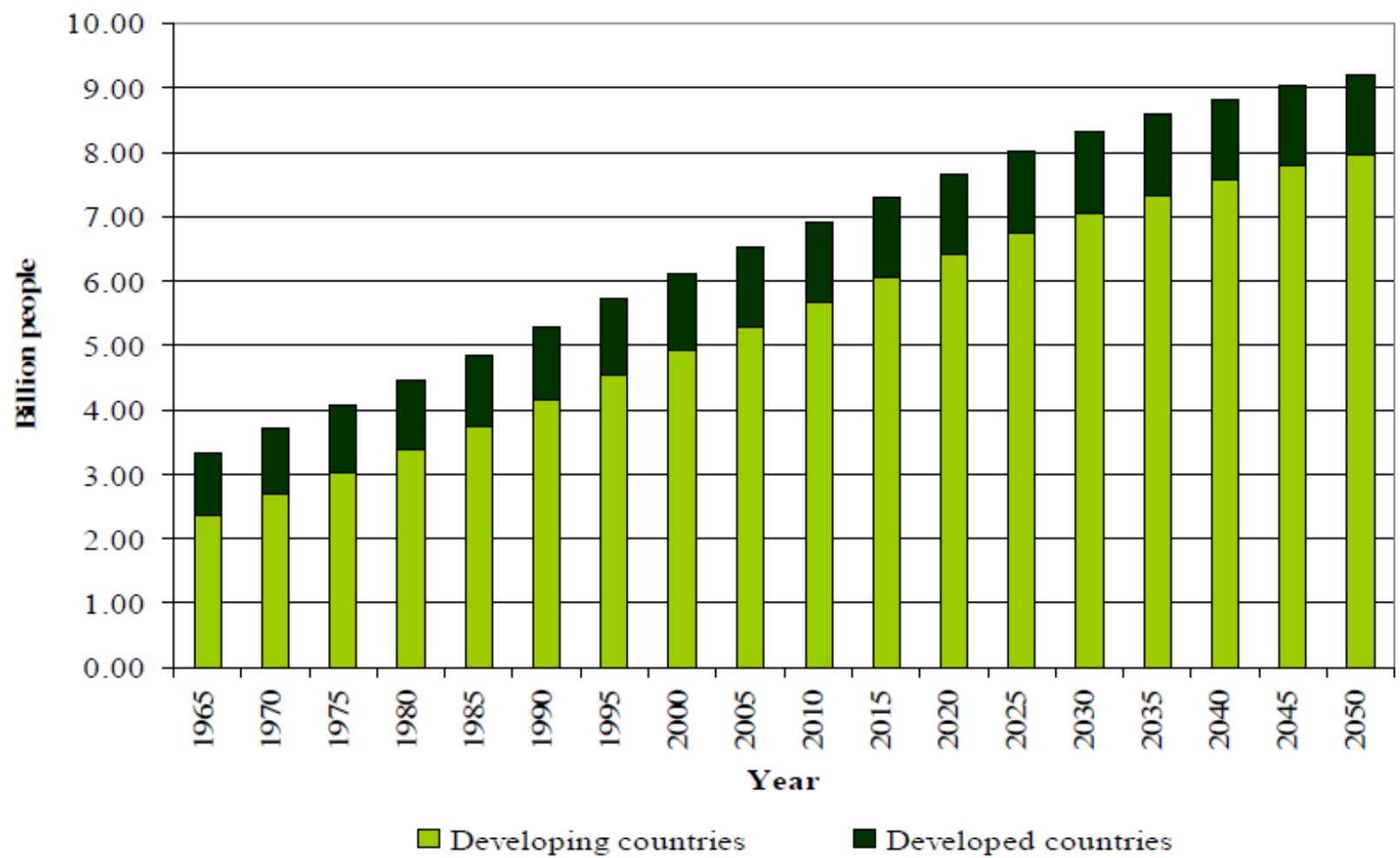

It has been proved that agricultural development has the capacity to encounter these challenges, particularly in those countries where agriculture is the major livelihood activity (Moremedi et al., 2018). Research studies are evident that in poverty reduction, farm economy plays a significant role as agriculture provides a food for increasing population, generates employment and establishes inter-sectorial linkages (Anowor et al., 2013). Corral et al. (2017) had endorsed that agriculture is driving force of rural economies and there is an urgent need to develop and promote sustainable development to improve the livelihoods of farming communities.

Research, education \& extension and farmers are the leading stakeholders of agricultural system (Lemma and Tesfaye, 2016; Deneke and Gulti, 2016). The performance and capability of each stakeholder to ensure rural food security depends on the continuous flow of agricultural knowledge and information among all stakeholders. Generally, the importance of information is well established in the life of every human being as it serves as a source of knowledge and skills for individuals (Odiaka, 2015). Particularly in the field of agricultural development access to information is one of the basic ingredients to increase farm productivity (Pandey, 2017). AguilarGallegos et al. (2015) had reported that to foster adoption of technologies, there is need of better exchange of information among farmers. This augments the vital importance of agricultural information among farmers to decide uptake of innovations.

Similar to other developing countries of the world, in Pakistan also, a wide variety of information sources are being used by farmers to get updated knowledge about farm practices to maximize farm profit and thereby improving livelihood (Ashraf et al., 2015) These sources may be a face-toface exchange of information between individuals or with the help of mass media (Rehman et al., 2013). In most cases, the type of information used by farmers depends upon the type of information being delivered (Zhang et al., 2016). Different factors influence the use of different information sources by the farming community. These factors may be social, economic, technical or cultural (Rehman et al., 2013). 
Creative Commons User License: CC BY-NC-ND

Abstracted by: EBSCOhost, Electronic Journals Service (EJS), Google Scholar, Journal Seek, Scientific Commons,

Food and Agricultural Organization (FAO), CABI and Scopus
Journal of Agricultural Extension

Vol. 23 (2) April, 2019

ISSN(e): 24086851; ISSN(Print); 1119944X

http://journal.aesonnigeria.org

http://www.ajol.info/index.php/jae

Email: editorinchief@aesonnigeria.org

\section{Purpose of the study}

The overall purpose of the study was to explore the factors that influence the application of ICTs in agriculture. The specific objectives were to:

- describe the demographic characteristics of farmers of the research area

- identify the level of availability and frequency of use of ICT tools for agriculture by the farmers in the research area

- identify the knowledge and skill level of respondents regarding the use of ICTs in agriculture

- find out the factors that influence the use of ICTs in agriculture

\section{Methodology}

The study was carried out in the Punjab province (Pakistan), which is very much famous due to its importance in the overall agricultural productivity of the country. Punjab province is located between latitudes $31.1704^{\circ} \mathrm{N}$ and longitudes $72.7097^{\circ} \mathrm{E}$. On the basis of area Punjab is the second largest province of Pakistan after Baluchistan with an area of 205,344 square kilometres $(79,284$ square miles). Punjab province occupies about $26 \%$ of the total land area of Pakistan. Lahore is the provincial capital of Punjab. On the agricultural basis, the province is divided into three different Agro-ecological regions Northern, Central and Southern. To have the representation of all the agro-ecological regions, one district from each region was selected randomly. List of farmers using ICTs as agricultural information collection \& sharing tool were collected from respective district agricultural extension offices. In each list, a total number of farmers using ICTs as an agriculture information tool on regular and active basis was about 100 . From each list, fifty (50) farmers were randomly selected and interviewed. The districts from where data were collected were Sargodha (central region), Khushab (northern region) and Vehari (southern region). The map of the Punjab province with targeted research areas is presented in Figure 2: 
Creative Commons User License: CC BY-NC-ND

Abstracted by: EBSCOhost, Electronic Journals Service (EJS), Google Scholar, Journal Seek, Scientific Commons,

Food and Agricultural Organization (FAO), CABI and Scopus
Journal of Agricultural Extension

Vol. 23 (2) April, 2019

ISSN(e): 24086851; ISSN(Print); 1119944X

http://journal.aesonnigeria.org

http://www.ajol.info/index.php/jae

Email: editorinchief@aesonnigeria.org

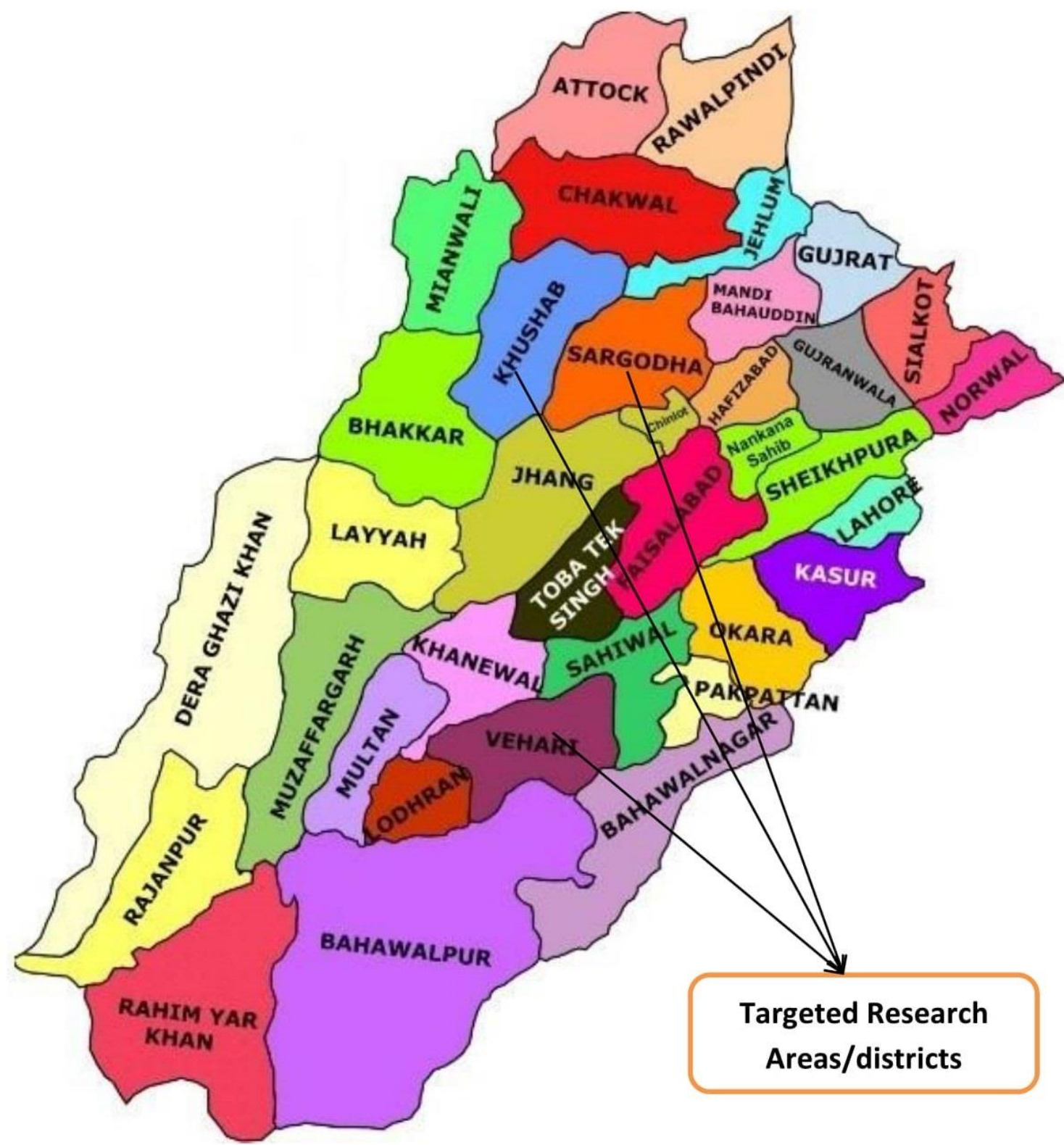

The consent of farmers to become part of the present research was taken telephonically. In the case of non-willingness, the process of random selection from the respective lists was repeated. The total sample size of respondents in the present study was 150. The data were collected during February-April, 2017. Self-administered interview schedule composed of close and openended questions was used as data collection and research instrument.

Interview schedule composed of two sections, the first section deal with socio-economic characteristics of respondents (age, educational level, size of land holding and income status). On the basis of the size of landholding, respondents were divided into three categories as small (having land up to 5 acres), medium (having land 6-10 acres), and large (having land 11 acres or above). On the basis of income, the respondents were categorized into three categories as poor (having monthly income up to 15,000.00 PKR), better-off (having monthly income 15,001.00 PKR to $30,000.00$ PKR) and well-off (having monthly income more than $30,000.00$ ).

Availability/access to ICTs by the respondents in the research area was measured as high (having ICT facility within the household), medium (having ICT facility in the home of nearby friends and neighbours) and low (have ICT facility in the urban centres). For measuring the extent of using 
Creative Commons User License: CC BY-NC-ND

Abstracted by: EBSCOhost, Electronic Journals Service (EJS), Google Scholar, Journal Seek, Scientific Commons,

Food and Agricultural Organization (FAO), CABI and Scopus
Journal of Agricultural Extension

Vol. 23 (2) April, 2019

ISSN(e): 24086851; ISSN(Print); 1119944X

http://journal.aesonnigeria.org

http://www.ajol.info/index.php/jae

Email: editorinchief@aesonnigeria.org

http://eoi.citefactor.org/10.11226/v23i2

ICTs, respondents were asked: "how many hours you utilize in one day in getting access to agricultural information through ICTs". In this way respondents were categorized into three categories as low (up to 2 hours per day), medium (3-4 hours per day), and high (five hours or above). Knowledge and skill level of respondents about ICTs was measured as high (operated ICT tools for agriculture by themselves), medium (operated ICT tools for agriculture by themselves mostly and sometimes with the help of other family members) and low (operated ICT tools for agriculture mostly with the help of other family members). Three-point Likert scale (1= Disagree, $2=$ Undecided, and $3=$ Agree) was used to rank the factors influencing the use of ICTs in agriculture. The ranking of factors was done on the basis of mean value.

The reliability of the same checked through test-re-test method while on the other hand the validity of the interview schedule was checked with the help of Cronbach Alpha using SPSS. Descriptive statistics were used to present data. Chi-square was used to see the association between demographic attributes of respondents as independent variables and extent/frequency of use of ICT tools in agriculture as the dependent variable. In chi-square test, statistical significance was accepted at a $P$ value of $\leq 0.05$. However, to find out the factors, which affect the access to agricultural information through ICTs by the farmers, multiple regression was applied. In regression analysis frequency/extent of using ICTs (FUICTs) served as dependent variable whereas access to ICTs (AICTs), Knowledge \& skills level of respondents regarding the use of ICTs in agriculture (KSICTs) and Income level possessed by respondents (IL) served as independent variables.

\section{Results and Discussion}

\section{Demographic Attributes of Respondents}

Table 1 shows that slightly more than half $(52.7 \%)$ of the respondents belonged to young age group having age upto 30 years. This indicates that young age group was more inclined towards information collection/sharing by the use of ICTs.

The majority of respondents $(72.0 \%)$ had only 8 years of schooling. Only $13.3 \%$ of respondents had 12 years of schooling. No respondent was found in the research area having graduation/university level education. This indicates that there is least trend among highly educated rural people to do farming. In most of the cases, it was found that illiteracy is very common in rural areas of Pakistan which is one of the major reasons behind the backwardness and prevailing poverty in rural areas (Rahman et al., 2015).

\section{Table 1: Demographic characteristics}

\begin{tabular}{lc}
\hline Demographic characteristics & Percent \\
\hline Age & 52.7 \\
Upto 30 years (young age group) & 23.3 \\
31 to 40 years (middle age group) & 24.0 \\
41 years and above (old age group) & 38.0 \\
Educational level & 34.0 \\
Upto primary & 14.7 \\
Middle & 13.3 \\
Matriculation & 44.7 \\
Intermediate & 40.7 \\
Size of landholding & 14.6 \\
Upto 5 acres (Small) & \\
6-10 acres (Medium) & 64.7 \\
Income status (Rs. Per month) & 19.3 \\
Upto 15000 (Poor) & 16.0 \\
15001 to 30,000 (Better-off) & \\
30,001 and above (Well-off) & \\
\hline
\end{tabular}

Source: Field survey, 2017 
Creative Commons User License: CC BY-NC-ND

Abstracted by: EBSCOhost, Electronic Journals Service (EJS), Google Scholar, Journal Seek, Scientific Commons,

Food and Agricultural Organization (FAO), CABI and Scopus
Journal of Agricultural Extension

Vol. 23 (2) April, 2019

ISSN(e): 24086851; ISSN(Print); 1119944X

http://journal.aesonnigeria.org

http://www.ajol.info/index.php/jae

Email: editorinchief@aesonnigeria.org

http://eoi.citefactor.org/10.11226/v23i2

In rural areas, the land is a symbol of power and status. In the research area, the majority (44.7\%) of respondents had only up to 5 (five) acres of agricultural land. Only $14.6 \%$ of respondents had more than eleven acres of agricultural land. This proves that small land holding is very common in the research area and generally in the whole country. Due to the small size of land holding, poverty persists in rural areas of Pakistan (Chaudhry et al., 2012). The majority of the respondents $(64.7 \%)$ were considered as poor. The prevailing high poverty status among farmers in the research area is due to the small size of agricultural land holding possessed by the respondents.

\section{ICT tools being used}

Different ICT tools or devices are being used by a rural community to get access to the latest and up-to-date agricultural information. In the present research, ICTs being used by the respondents in most of the cases to get agricultural related information were identified and the data in this regard is presented in Table 2 .

Table 2: ICT tools used by respondents

\begin{tabular}{lc}
\hline ICTs Device/ Tools & Percentage $^{*}$ \\
\hline Radio & 10.0 \\
Television & 24.7 \\
Internet & 32.7 \\
Computer & 15.3 \\
Mobile phone & 47.3 \\
Telephone & 18.7 \\
Social Media & 12.7 \\
\hline Source: Field survey, 2017 & ${ }^{*}$ "Multiple responses
\end{tabular}

Table 2 shows that the majority of the respondents (47.3\%) were using mobile/cell phone to get access to agricultural related information and knowledge. Other ICT tools which were being used by the farmers of research area were internet, television, telephone, social media and radio as reported by $32.7 \%, 24.7 \%, 18.7 \%, 12.7 \%$ and $10.0 \%$ of respondents, respectively. In connection with these findings, Butt et al. (2017) concluded that the majority of the farmer is being used a cell phone as well as a telephone to seek information for agricultural marketing, micro-credit disbursement and crop management practices.

\section{Availability and Access to ICTs as Agricultural Information Source}

Availability and access to any technology is the key component for its efficient and effective use by the respective community. In the present study, the availability of ICTs tools for getting access to agricultural information was assessed and categorized as low, medium and high. The data in this regard is tabulated in Table 3.

Table 3: Availability and access to ICTs as agricultural information source

\begin{tabular}{lc}
\hline Level & Percent \\
\hline Low & 56.7 \\
Medium & 28.0 \\
High & 15.3 \\
Total & $\mathbf{1 0 0 . 0}$ \\
\hline
\end{tabular}


Creative Commons User License: CC BY-NC-ND

Abstracted by: EBSCOhost, Electronic Journals Service (EJS), Google Scholar, Journal Seek, Scientific Commons,

Food and Agricultural Organization (FAO), CABI and Scopus
Journal of Agricultural Extension

Vol. 23 (2) April, 2019

ISSN(e): 24086851; ISSN(Print); 1119944X

http://journal.aesonnigeria.org

http://www.ajol.info/index.php/jae

Email: editorinchief@aesonnigeria.org

http://eoi.citefactor.org/10.11226/v23i2

Table 2 shows that the availability of ICT tools in the research area is very low as reported by the majority $(56.7 \%)$ of respondents. Only a minor percentage $(15.3 \%)$ of respondents reported a high level of availability of ICTs and their usage in farming operations and practices as well as getting up-to-date agricultural information and knowledge. These results are similar to those of Tanko et al. (2013) as poor accessibility and availability of ICTs among users was reported poor. Aromolaran et al. (2016) had reported that farmers were not getting desired benefits from the use of ICTs due to limited availability and accessibility among farmers.

\section{Knowledge and Skill level of Respondents Regarding the use of ICTs in agriculture}

Knowledge and skill level of respondents regarding the use of ICTs in agriculture (in farming practices performed by respondents) were categorized as low, medium and high. The data in this regard is given in Table 4.

Table 4: Knowledge and skill level in the use of ICTs for agriculture

\begin{tabular}{lc}
\hline Level & Percent \\
\hline Low & 30.0 \\
Medium & 53.3 \\
High & 16.7 \\
Total & 100.0 \\
\hline
\end{tabular}

Source: Field survey, 2017

Scale: $1=$ low, $2=$ Medium and $3=$ High

The data presented in Table 4 shows that respondents had knowledge and skill of medium level to use ICTs as perceived by the greater than half respondents (53.3\%). Similar findings were reported by Kabir (2015) as 50\% of respondents had a medium level of knowledge on the use of ICTs. Of the total respondents, less than one fifth (16.7\%) respondents had a high level of knowledge and skill to access required information from ICTs. Furthermore, $30 \%$ of respondents reported their low level of knowledge and skill to use ICTs to meet their information needs. This implies that respondents are not enjoying the full potential of ICTs as their knowledge and skill are hindering the level of use. Osondu \& Ibezim (2015) arbitrated that inadequate knowledge and awareness of ICTs use among farmers allow them to get benefits partially. With the unit increase in their knowledge and skill can ensure the increased use of ICTs among farmers.

\section{Frequency/extent of using ICTs in agriculture}

Table 5 illustrates that the majority of the respondents (64.7\%) fell in the category of low-level users of different ICTs. Duration of use of ICTs among these respondents was of less than 2 hours in a day. They opined in an informal discussion that they are information seekers and use ICTs to get the required information.

Table 5: Eextent of using ICTs in agriculture

\begin{tabular}{lc}
\hline Level & Percent \\
\hline Low (use ICTs for less than 2 hours per & 64.7 \\
day) & 21.3 \\
Medium (use ICTs for 3-4 hours per day) & 14.0 \\
High (use ICTs for 5 hours or more per & $\mathbf{1 0 0 . 0}$ \\
day) & \\
Total &
\end{tabular}

Source: Field survey, 2017

Scale: $1=$ low, 2=Medium and $3=$ High 
Creative Commons User License: CC BY-NC-ND

Abstracted by: EBSCOhost, Electronic Journals Service (EJS), Google Scholar, Journal Seek, Scientific Commons,

Food and Agricultural Organization (FAO), CABI and Scopus
Journal of Agricultural Extension

Vol. 23 (2) April, 2019

ISSN(e): 24086851; ISSN(Print); 1119944X

http://journal.aesonnigeria.org

http://www.ajol.info/index.php/jae

Email: editorinchief@aesonnigeria.org

http://eoi.citefactor.org/10.11226/v23i2

Mtega and Msungu (2013) had the same results that farmers accessed agricultural information from ICTs. Whereas, slightly greater than one fifth $(21.3 \%)$ respondents fell in the category of medium level users as they had use of ICTs for 3-4 hours a day. Fourteen percent had used of ICTs for more than 5 hours a day. These users commented in an informal discussion that they had multiple uses of ICTs including information and entertainment. Thus, they spend more time on ICTs. They made an argument that pertinent to extensive use of ICTs they had more information and knowledge about the latest and site-specific technologies of farming. Similar results were reported by the Syiem \& Raj (2015) as farmers' knowledge regarding availability and accessibility of inputs, diseases management and crop management escalated due to ICTs use. Sharma et al. (2012) cemented an increased penetration of ICTs among farmers to uptake agricultural technologies.

\section{Association between Demographic Attributes and frequency/extent of using ICTs as an agriculture information tool}

Table 6 reports a significant association of size of land holding size and income level of the respondents a highly significant with the level of use of ICTs to perceived agricultural information. Whereas, age and education of respondents had a positive but non-significant association with the level of use of ICTs.

Table 6. Association between selected demographic attributes and frequency/extent of using ICTs as an agriculture information tool

\begin{tabular}{lccc}
\hline Variable & $\mathbf{X}^{2}$ cal value & DF & Gama \\
\hline Age & 3.771 & 4 & 0.438 \\
Education & 6.920 & 6 & 0.328 \\
Size of land holding & $15.186^{\star *}$ & 4 & 0.004 \\
Income level & $67.265^{\star * *}$ & 4 & 0.000 \\
\hline
\end{tabular}

${ }^{*} \mathrm{P} \leq 0.05$. Source: Field survey, 2017

Size of land holding $\left(X^{2}=15.186\right)$ arbitrates that with the unit increase in land holding size of the respondents will drive farmers towards more use of ICTs. This further implies that with the increase in the size of land holding information needs of the farmers will increase followed by the increase in the level of use of ICTs to bridge the information gap. Similar perception supports the relationship between the income level of respondents and the level of use of ICTs $\left(\mathbf{X}^{\mathbf{2}}=67.265\right)$. The results elaborate that as the income level of farmer rises the use of ICTs will increase to escalate the benefits. The increased income level of the farmer can persuade farmers to access advanced ICTs as well to cope with information needs. Number of research studies affirm a strong association between the size of land holding size and income level of farmers in rural settings. The size of land holding in rural areas predicts the level of income of farmer (Ojo \& Babayo, 2013; Pervaiz et al., 2013). The results reported by the Syiem \& Raj (2015) found a significant relationship of income of farmers with the use of ICTs.

Age and education are one of the prominent socio-economic attributes of the respondents and had a significant contribution in the adoption of agricultural innovations and uptake of modern technologies i.e. ICTs. Syiem \& Raj (2015) reported that age and education had a significant association with the use of ICTs. Omotesho et al. (2012) reported a significant association between education and the use of ICTs among farmers. In this study, both of these attributes had a non-significant but positive relationship with the level of use of ICTs. The positive relationship describes that there is a likelihood of an increase in the use of ICTs. For instance, increase in the 
Creative Commons User License: CC BY-NC-ND

Abstracted by: EBSCOhost, Electronic Journals Service (EJS), Google Scholar, Journal Seek, Scientific Commons,

Food and Agricultural Organization (FAO), CABI and Scopus
Journal of Agricultural Extension

Vol. 23 (2) April, 2019

ISSN(e): 24086851; ISSN(Print); 1119944X

http://journal.aesonnigeria.org

http://www.ajol.info/index.php/jae

Email: editorinchief@aesonnigeria.org

http://eoi.citefactor.org/10.11226/v23i2

educational level of the respondents can enhance the level of use of ICTs. Some of the studies are evident with the increasing age use of ICTs weakens. However, in this research the notion of an increase in the use of ICTs with the increasing age is prominent. The reason could be the userfriendliness, cosmopolitans and being a source of infotainment had wipe out the barriers and allowed a human being to use ICTs irrespective of their socio-economic characteristics. Omotesho et al. (2012) arbitrated that with the increasing age use of ICTs may decrease. They were of the view that with the increasing age human beings become more resistant to change and innovations.

\section{Factors Influencing Use of ICTs in Agriculture}

Table 7 shows that electricity/power failure was top $(\bar{X}=2.95 / 3.00)$ while illiteracy $(\bar{x}=2.15 / 3.00)$ was the least constraint militating use of ICTs. Among constraints, the barrier of language was ranked second ( $\bar{x}=2.93 / 3.00)$ and limited knowledge and skills to use ICTs was ranked third. knowledge and skills are important factors to understand and utilise ICTs effectively. In the study area the level of knowledge and skills to use ICTs is less than medium level (see Table 4).

Table 7: Factors influencing the use of ICTs in agriculture

\begin{tabular}{lccc}
\hline Factors & Mean & SD & Rank Order \\
\hline Electricity/power failure & 2.95 & 0.212 & 1 \\
Language barriers (as the majority of the text is in & & & \\
English) & 2.93 & 0.250 & 2 \\
Limited knowledge and skills in ICT tools & 2.89 & 0.310 & 3 \\
High cost & 2.87 & 0.334 & 4 \\
Limited availability of ICT tools & 2.85 & 0.355 & 5 \\
Limited authenticity of information posted on & & & \\
internet & 2.84 & 0.368 & 6 \\
Limited availability and poor internet coverage & 2.82 & 0.479 & 7 \\
Availability of irrelevant/ undesirable content & 2.73 & 0.587 & 8 \\
Internet connectivity issues & 2.68 & 0.559 & 9 \\
Illiteracy & 2.15 & 0.721 & 10 \\
\hline
\end{tabular}

Source: Field survey, 2017

Scale: $1=$ Disagree, $2=$ Undecided, $3=$ Agree

Furthermore, high cost $(\bar{x}=2.87 / 3.00)$, Limited availability of ICT tools $((\bar{x}=2.85 / 3.00)$, limited authenticity of agricultural information posted on internet $(\bar{x}=2.84 / 3.00)$, limited availability and poor internet coverage $(\bar{x}=2.82 / 3.00)$, availability of irrelevant/ undesirable content posted on internet $(\bar{x}=2.73 / 3.00)$ and internet connectivity issues $(\bar{x}=2.68 / 3.00)$ were ranked $4^{\text {th }}, 5^{\text {th }}, 6^{\text {th }}, 7^{\text {th }}$, $8^{\text {th }}$ and $9^{\text {th }}$ respectively. These results are similar to those of Oyeyinka and Bello (2013) as they found a high cost of ICTs a major barrier affecting use of ICTs. Results are further supported by Ajani \& Agwu (2012) and Shankariah \& Swamy (2012) as they found that inconsistent power failure and poor internet connectivity hindered the use of ICTs among farmers. Findings augments that electricity shortage and availability of slow internet connections particularly in rural areas were perceived leading barriers by the farmers to hinder their access to information. During informal discussion respondents showed dissatisfaction with contents available online. They viewed the contents available online unauthentic and overloaded. They lack in skills to screen suitable, reliable, valid and practical information from the plethora of information available online. Similar results were presented by Shankariah \& Swamy (2012) as they reported that farmers had minimal practical exposure while accessing information from ICTs. 
Creative Commons User License: CC BY-NC-ND

Abstracted by: EBSCOhost, Electronic Journals Service (EJS), Google Scholar, Journal Seek, Scientific Commons,

Food and Agricultural Organization (FAO), CABI and Scopus
Journal of Agricultural Extension

Vol. 23 (2) April, 2019

ISSN(e): 24086851; ISSN(Print); 1119944X

http://journal.aesonnigeria.org

http://www.ajol.info/index.php/jae

Email: editorinchief@aesonnigeria.org

\section{http://eoi.citefactor.org/10.11226/v23i2}

There is a significant relationship between the age of the respondents and the availability of ICT tools. There is a significant association of the extent of using ICTs for agricultural information with landholding and educational level of farmers in the study area. Similarly, a significant correlation was observed between the dependent variable (extent of using ICTs) and independent variables (access to ICTs, knowledge \& skills level regarding ICT use in agriculture and income level). Hence, rural youth has more accessibility to ICT tools for agricultural information. The farmers in the research area have medium level knowledge and skills to utilize ICTs in agricultural practices. But utilization of ICTs by the majority of the farmers in the study area is low as reported by the majority of respondents. The results also revealed that electricity/power issues, language barriers, limited knowledge and skills about ICT tools, high cost and limited availability of ICTs were the prominent factors militating use of ICTs. This study recommends that government should initiate different agricultural technology transfer programmes in liaison with national and multi-national private telecommunication companies to enhance accessibility of ICTs to farmers. There is further need for mass awareness to escalate the use of ICTs in agricultural avenues. Agriculture department should focus to made agricultural related information available online preferably in local language.

\section{References}

Aguilar-Gallegos, N., Muñoz-Rodríguez, M., Santoyo-Cortés, H., Aguilar-Ávila, J. and Klerkx, L., (2015). Information networks that generate economic value: A study on clusters of adopters of new or improved technologies and practices among oil palm growers in Mexico. Agricultural Systems, Vol 135, pg122-132.

Ajani, E.N. \& Agwu, A.E. (2012) Information communication technology needs of small scale farmers in Anambra state, Nigeria. Journal of Agricultural and Food Information, Vol 13, Issue 2, pg144-156.

Anowor, O.F., Ukweni, N.O. and Ezekwem, S.O., (2013). Agricultural productivity and poverty alleviation: an econometric analysis. American Journal of Sustainable Cities \& Society, Vol 2, Issue 1, pg.109-29.

Ashraf, S., Khan, G. A., Ali, S., Ahmed, S., \& Iftikhar, M. (2015). Perceived effectiveness of information sources regarding improved practices among citrus growers in Punjab, Pakistan. Pakistan Journal of Agricultural Sciences, Vol 52, Issue 3, pg 861-866.

Butt, T.M., Qijie, G., Hassan, M.Z.Y., Luqman, M., Khan, M., Tian, X., \& Mehmood, K. (2017). An exploration of information communication technology (ICTS) in agricultural development: The experiences of rural Punjab-Pakistan. Transylvanian Review, Vol. 16, issue XXV, pg 4087-4096.

Chaudhry, I.S., Faridi, M. Z. \& Hanif, I. (2012). The whimsical trends of rural poverty in Pakistan: some diversifications. International Research Journal of Finance and Economics, Issue 83, pg 78-89.

Corral, S., Díaz, A., Monagas, M. and García, E., (2017). Agricultural policies and their impact on poverty reduction in developing countries: Lessons learned from three water basins in Cape Verde. Sustainability, Vol 9, Issue 10, pg1841.

Deneke, T.T. and Gulti, D., (2016). Agricultural Research and Extension Linkages in the Amhara Region, Ethiopia. In Technological and Institutional Innovations for Marginalized Smallholders in Agricultural Development (pp. 113-124). Springer, Cham. 
Creative Commons User License: CC BY-NC-ND

Abstracted by: EBSCOhost, Electronic Journals Service (EJS), Google Scholar, Journal Seek, Scientific Commons,

Food and Agricultural Organization (FAO), CABI and Scopus
Journal of Agricultural Extension

Vol. 23 (2) April, 2019

ISSN(e): 24086851; ISSN(Print); 1119944X

http://journal.aesonnigeria.org

http://www.ajol.info/index.php/jae

Email: editorinchief@aesonnigeria.org

http://eoi.citefactor.org/10.11226/v23i2

Ehrlich, P. R., \& Harte, J. (2015). Opinion: To feed the world in 2050 will require a global revolution. Proceedings of the National Academy of Sciences, Vol 112, Issue 48, pp 1474314744.

Kabir, K. H. (2015). Attitude and level of knowledge of farmers on ICT based farming. European Academic Research, Vol 2, Issue 10, pg 13177-13196.

Lemma, M. and Tesfaye, B., (2016). From research-extension linkages to innovation platforms: Formative history and evolution of multistakeholder platforms in Ethiopia. Journal of Agricultural Economics, Extension and Rural Development, Vol 4, Issue 7, pg 496-504.

Moremedi, G., Hulela, K. \& Maruatona, T.L. (2018). Factors perceived to influence the adoption of improved technologies in arable farming in the Southern district of Botswana. International Journal of Agricultural Extension, Vol 6, issue 3, pg 193-202.

Mtega, W.P \& Msungu, A.C. (2013) Using information and communication technologies for enhancing the accessibility of agricultural information for improved agricultural production in Tanzania. The Electronic Journal on Information Systems in Developing Countries, Vol 56, Issue 1, pg 1-14

Odiaka, E. (2015). Perception of the influence of home videos on youth farmers in Makurdi, Nigeria. Journal of Agricultural \& Food Information, Vol 16, Issue 4, pg 337 346.

Ojo, C.O. \& Babayo, U.A. (2013). Analysis of gender contribution to rural household food supply (A case study of Askira/ Uba local government area, Borno State). Greener Journal of Agricultural Sciences, Vol 3, issue 3, pg 240-245.

Omotesho, K.F., I. O. Ogunlade \& L. Muhammad. (2012). Assessment of access to information and communication technology among agricultural extension officers in Kwara State, Nigeria", Asian Journal Agriculture and Rural Development, Vol 2, Issue 2, pg 220-225.

Osondu, C. K., \& Ibezim, G. M. C. (2015). Awareness and perception of farmers to the use of information and communication technologies (ICTs) in agricultural extension service delivery: A case study of Imo State, Nigeria. International Journal of Agriculture Innovations and Research, Vol 4 Issue 1, pg 55-60.

Oyeyinka, R.A. \& Bello, R.O. (2013) Farmers Use of ICTs for marketing information outlets in Oyo State, Nigeria. Journal of Agricultural Science, Vol 5, Issue 1, pg150-158.

Pandey, N. (2017). Role of information and communication technology in agriculture development: a study of Nabarangpur district, Scholedge International Journal of Business Policy \& Governance, Vol04, Issue 04, Pg 24-35.

Pervaiz, U., Khan, F., Jan, D., Zell-e-Huma. \& Zafarullah, M. (2013). An analysis of sugarcane production with reference to extension services in union council Malakandher - Peshawar. Serhad Journal of Agriculture, Vol 29, issue 1, pg 145-150.

Rehman, A., Jingdong, L., \& Hussain, I. (2015). The province-wise literacy rate in Pakistan and its impact on the economy. Pacific Science Review B: Humanities and Social Sciences, Vol 1 Issue 3, pg 140-144.

Rehman, F., Muhammad, S., Ashraf, I., Chaudhary, K.M., Ruby, T. \& Bibi, I. (2013). Effect of farmers' socioeconomic characteristics on access to agricultural information: Empirical evidence from Pakistan. The Journal of Animal \& Plant Sciences, Vol 23, issue1, pg 324329. 
Creative Commons User License: CC BY-NC-ND

Abstracted by: EBSCOhost, Electronic Journals Service (EJS), Google Scholar, Journal Seek, Scientific Commons,

Food and Agricultural Organization (FAO), CABI and Scopus
Journal of Agricultural Extension

Vol. 23 (2) April, 2019

ISSN(e): 24086851; ISSN(Print); 1119944X

http://journal.aesonnigeria.org

http://www.ajol.info/index.php/jae

Email: editorinchief@aesonnigeria.org

http://eoi.citefactor.org/10.11226/v23i2

N. (2012). Mobile communication as a viable tool for Agriculture and Rural Development. Proceedings of Mobiles for Development held on 2012. Department of Agricultural Extension, University of Agricultural Sciences, Bangalore.

Sharma, M., Kaur, G. and Gill, M.S. (2012) Use of Information and Communication Technology in agriculture by farmers of Kapurthala District. Journal of Krishi Vigyan Kendra, Vol 1 Issue 1 , pg 82-89.

Syiem, R. \& S. Raj. (2015). Access and usage of ICTs for agriculture and rural development by the tribal farmers in Meghalaya State of North-East India. Journal of Agricultural Informatics, Vol. 6, Issue 3, pg 24-41.

Zhang, Y., Wang, L. and Duan, Y. (2016). Agricultural information dissemination using ICTs: A review and analysis of information dissemination models in China. Information processing in agriculture, Vol 3, Issue 1, pg17-29. 